\title{
Cell Division in the Yeast Saccharomyces cerevisiae Growing at Different Rates
}

\author{
By G. C. JOHNSTON, ${ }^{*}$ R. A. SINGER, ${ }^{2}$ S. O. SHARROW ${ }^{3}$ AND \\ M. L. SLATER ${ }^{3}$ \\ ${ }^{1}$ Department of Microbiology, Dalhousie University, Halifax, Nova Scotia, \\ Canada \\ ${ }^{2}$ Departments of Biochemistry and Medicine, Dalhousie University, Halifax, Nova Scotia, \\ Canada \\ ${ }^{3}$ National Institutes of Health, Bethesda, Maryland, U.S.A.
}

(Received 2 August 1979; revised 14 December 1979)

\begin{abstract}
Flow microfluorometry was employed to examine the cell cycle of Saccharomyces cerevisiae growing at different rates governed by different nitrogen sources. In general, the initiation of budding was indistinguishable from the onset of $S$ phase regardless of growth rate. Although with longer generation times $S$ phase showed some increase in length, most of the increase in generation time resulted from increases in G1.
\end{abstract}

\section{INTRODUCTION}

The yeast Saccharomyces cerevisiae reproduces by the formation of a bud. We have suggested (Johnston et al., 1977a; Carter et al., 1978) that once budding is initiated, cells proceed through the remainder of the cell cycle at a relatively constant rate regardless of generation time. Previous studies in which growth rates were altered by limiting glucose concentration in chemostats (Jagadish \& Carter, 1977), by using different carbon sources (Slater et al., 1977), or by treating cells with low concentrations of cycloheximide (Hartwell \& Unger, 1977), demonstrated that changes in growth rate are mainly reflections of altered lengths of the G1 phase of the cell cycle and that the initiation of budding, or bud emergence, is coincident with the initiation of DNA synthesis.

Our work on the relationship between cell cycle duration and growth involved varying growth rates by using different carbon sources (Slater et al., 1977). The proportions of cells in $\mathrm{G} 1, \mathrm{~S}$ and $\mathrm{G} 2$ were determined using flow microfluorometric analysis. As the generation time increased, the proportion of cells in G1 also increased, as did the time spent in G1. The proportions of cells in S and G2 decreased; the time spent in S remained constant, while the time spent in G2 increased slightly. Here we report results of a similar study in which growth rates were governed by different nitrogen sources. As the generation time increased with different nitrogen sources the proportion of cells in G1 again increased, as did the time spent in G1. However, we found that the proportion of cells in $\mathrm{S}$ remained relatively constant, while the proportion of cells in G2 decreased. The time spent in S phase increased slightly with increasing generation times, compared with increases in $G 1$, whereas the time spent in G2 remained relatively constant. The variations in the lengths of S and G2 were small compared with the variations in the length of $\mathrm{G} 1$, which accounted for most of the variation in generation time. The proportion of cells in G1 was generally the same as the proportion of cells without buds. 


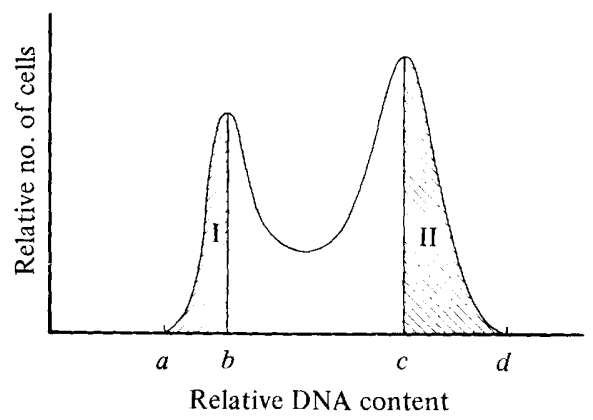

Fig. 1. Analysis of population DNA distribution. Point $b$ was obtained by integrating over adjacent 5-channel intervals near the first peak of the curve and choosing the midpoint of the interval giving the highest value. Point $c$ was similarly determined. Areas I and II were obtained as integrals over the intervals $a$ to $b$ and $c$ to $d$, respectively.

\section{METHODS}

Strain and growth conditions. The diploid Saccharomyces cerevisiae strain X2180 (ATCC 26109) was grown at $23{ }^{\circ} \mathrm{C}$ in YNB medium (Johnston et al., 1977b) (made with Difco yeast nitrogen base without amino acids or ammonium sulphate) containing $2 \%(\mathrm{w} / \mathrm{v})$ glucose and modified by the addition of various nitrogen sources as described in Results. All nitrogen sources were employed at a final concentration of $0 \cdot 1 \%(\mathrm{w} / \mathrm{v})$. Cultures were maintained in the exponential phase of growth between densities of $5 \times 10^{5}$ and $5 \times 10^{6}$ cells $\mathrm{ml}^{-1}$ for $3 \mathrm{~d}$ prior to analysis. The proportions of cells without buds were determined by direct microscopic examination (Hartwell, 1970).

Analysis of cell cycle phases. The proportions of cells in the various phases of the cell cycle were calculated from plots of the DNA contents of cells under different steady-state growth conditions. The calculations have been described in detail elsewhere (Slater et al., 1977) and are briefly described here. After staining yeast with the nuclear stain mithramycin (Tobey \& Chrissman, 1975), passage of cells through a flow microfluorometer generates a relative DNA content distribution for the population. As shown in Fig. 1, points $b$ and $c$ represent the relative DNA content of cells in G1 and G2, respectively. The fraction of the population of cells in G1 can be determined as twice the area I divided by the integral from $a$ to $d$. Similarly, the proportion of cells in G2 can be determined as twice the area II divided by the integral from $a$ to $d$. This method of calculation is necessary since cells in $\mathrm{S}$ will cause each peak in Fig. 1 to be skewed. The proportion of cells in $\mathrm{S}$ is that not accounted for by $\mathrm{G} 1$ or $\mathrm{G} 2$.

The times in various stages of the cell cycle were calculated using the following equations (Slater et al., 1977):

$$
\begin{aligned}
& T(\mathrm{G} 1)=-\left(t_{\mathrm{D}} / \ln 2\right) \ln [1-P(\mathrm{G} 1)] \\
& T(\mathrm{~S})=\left(t_{\mathrm{D}} / \ln 2\right) \ln [1+P(\mathrm{~S}) /\{1+P(\mathrm{G} 2)\}] \\
& T(\mathrm{G} 2)=\left(t_{\mathrm{D}} / \ln 2\right) \ln [1+P(\mathrm{G} 2)]
\end{aligned}
$$

where $P(\mathrm{X})$ is the proportion of cells in phase $\mathrm{X}, T(\mathrm{X})$ is time spent in phase $\mathrm{X}$ and $t_{\mathrm{D}}$ is the doubling time.

\section{RESULTS AND DISCUSSION}

\section{Cell cycle parameters of cells growing at different growth rates}

Growth rates of cultures were altered by using different nitrogen sources (see Table 1). These led to generation times between $2 \cdot 4$ and $7 \cdot 6 \mathrm{~h}$. In each case, longer generation times were accompanied by larger proportions of cells without buds.

Using the method for cell cycle analysis described in Methods, we determined from flow microfluorometric analysis plots (Fig. 2) that the proportions of cells with DNA contents characteristic of cells in G1 increased with increasing generation times. This relationship is shown in Fig. 3. The proportions of cells in G1 as determined from flow microfluorometric analysis were almost identical to those determined by scoring cells without buds by direct microscopic examination (Table 1). Thus our analysis is consistent with coincident initiation of budding and initiation of $\mathrm{S}$ phase under these different growth conditions. 

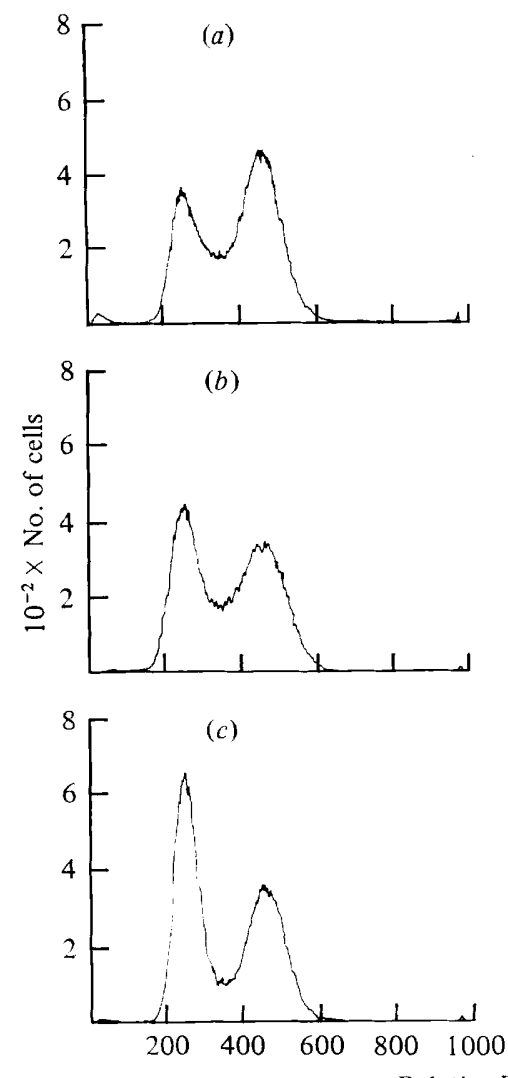
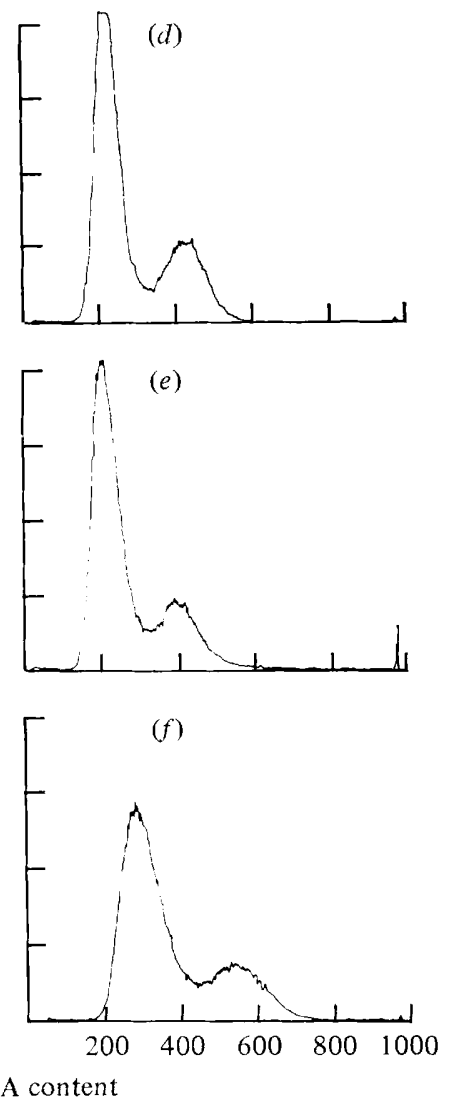

Fig. 2. Flow microfluorometric analysis of population DNA contents. Cells of the diploid strain X2180 were maintained in steady-state growth for several days using different nitrogen sources. DNA distributions are shown for cells grown with $(a)$ glutamate, $(b)\left(\mathrm{NH}_{4}\right)_{2} \mathrm{SO}_{4}$, (c) leucine, $(d)$ tryptophan, $(e)$ proline and $(f)$ threonine as nitrogen sources.

Also shown in Table 1 are the proportions of the cells in S phase and in G2 phase. Unlike our previous findings from experiments using different carbon sources (Slater et al., 1977), this work shows that the proportion of the cell population in S remained essentially unchanged at different growth rates, while the proportion of the population in G2 varied somewhat.

As a control for our method of cell cycle analysis, cells were exposed to the protein synthesis inhibitor cycloheximide before flow microfluorometric analysis. Cells exposed to cycloheximide are able to complete but not initiate DNA synthesis (Hereford \& Hartwell, 1973). Therefore, cells in $S$ at the time of cycloheximide addition will continue through $S$ and arrest in G2; cells in G1 at the time of cycloheximide addition will fail to initiate DNA synthesis and will remain in G1. When cultures growing at different rates were exposed to cycloheximide $\left(100 \mu \mathrm{g} \mathrm{ml}^{-1}\right)$ for $4 \mathrm{~h}$ before flow microfluorometric analysis, the proportions of cells in G1 were approximately the same (except for threonine-grown cells; see below) as those found for untreated populations (Table 1). Cells in G2 plus cells in G1 accounted for essentially all cells in the cycloheximide-treated populations (results not shown). These findings suggest that the method for determining the proportions of cells in G1 and G2 during normal growth is unaffected by the presence of $\mathrm{S}$ phase cells. 


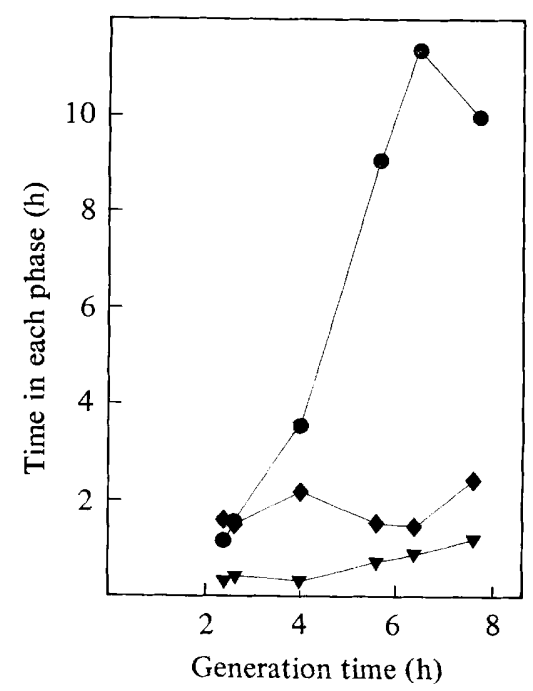

Fig. 3. Duration of phases of the cell cycle at different growth rates. The flow microfluorometric analysis plots illustrated in Fig. 2 were analysed according to the 'mixed mother-daughter' model of cell division (Slater et al., 1977) to determine the times spent in each phase of the cell cycle for cells grown with different nitrogen sources: - , time in $\mathrm{G} 1 ; \diamond$, time in $\mathrm{G} 2 ; \boldsymbol{\nabla}$, time in $\mathrm{S}$.

\section{Table 1. Duration of phases of the cell cycle at different growth rates}

Results presented are based on the distributions shown in Fig. 2.

\begin{tabular}{|c|c|c|c|c|c|c|c|c|c|c|}
\hline \multirow[b]{3}{*}{$\begin{array}{l}\text { Nitrogen } \\
\text { source }\end{array}$} & \multirow[b]{3}{*}{$\begin{array}{c}\text { Doubling } \\
\text { time (h) }\end{array}$} & \multirow[b]{3}{*}{$\begin{array}{l}\text { Percentage of } \\
\text { unbudded cells }\end{array}$} & \multicolumn{4}{|c|}{$\begin{array}{l}\text { Percentage of cells in each } \\
\text { phase }\end{array}$} & \multirow{2}{*}{\multicolumn{4}{|c|}{ Time in each phase $(\mathrm{h})$}} \\
\hline & & & \multicolumn{2}{|c|}{ G1 } & \multirow[b]{2}{*}{$\mathrm{G} 2 *$} & \multirow[b]{2}{*}{$\mathrm{S}^{*}$} & & & & \\
\hline & & & I* & $\widetilde{\mathrm{II} \dagger}$ & & & G1 & $\mathrm{S}$ & G2 & $\mathrm{S}+\mathrm{G} 2$ \\
\hline Glutamate & $2 \cdot 4$ & 27 & $28 \cdot 5$ & $33 \cdot 0$ & $56 \cdot 7$ & $14 \cdot 8$ & $1 \cdot 16$ & $0 \cdot 31$ & $1 \cdot 56$ & 1.87 \\
\hline$\left(\mathrm{NH}_{4}\right)_{2} \mathrm{SO}_{4}$ & $2 \cdot 6$ & 35 & $34 \cdot 1$ & $35 \cdot 8$ & $49 \cdot 0$ & $16 \cdot 9$ & $1 \cdot 56$ & 0.40 & $1 \cdot 50$ & $1 \cdot 90$ \\
\hline Leucine & $4 \cdot 0$ & 54 & $46 \cdot 0$ & $49 \cdot 6$ & $46 \cdot 0$ & $8 \cdot 0$ & $3 \cdot 56$ & 0.31 & $2 \cdot 18$ & $2 \cdot 49$ \\
\hline Tryptophan & $5 \cdot 6$ & 72 & $67 \cdot 5$ & $68 \cdot 5$ & $21 \cdot 0$ & $11 \cdot 5$ & 9.08 & 0.73 & 1.54 & $2 \cdot 27$ \\
\hline Proline & $6 \cdot 4$ & 75 & $71 \cdot 0$ & $75 \cdot 0$ & $17 \cdot 1$ & 11.9 & $11 \cdot 40$ & 0.89 & $1 \cdot 46$ & $2 \cdot 35$ \\
\hline Threonine & $7 \cdot 6$ & 80 & $60 \cdot 0$ & $70 \cdot 0$ & $25 \cdot 3$ & $14 \cdot 7$ & $10 \cdot 00$ & $1 \cdot 22$ & 2.47 & 3.69 \\
\hline
\end{tabular}

* Percentages of cells in G1, G2 and S calculated as described in Methods.

† Percentage of cells in G1 calculated as the area under the first peak after the cells had been treated with cycloheximide (see Slater et al., 1977).

$\ddagger$ Calculations based on the 'mixed mother-daughter' model as described by Slater et al. (1977).

\section{Duration of $\mathrm{G} 1, \mathrm{~S}$ and $\mathrm{G} 2$}

Cell division of yeast generates cells of unequal size (Hartwell \& Unger, 1977). Moreover, regardless of growth rate, cells must attain some critical size for initiation of budding (Johnston et al., 1977b; 1979). The 'mixed mother-daughter' model of cell division (Slater et al., 1977) assumes that the mother cell after cytokinesis immediately initiates a bud, whereas the smaller daughter cell must grow to the size of the mother cell before budding. The cell cycle times of daughter cells are longer than those of mother cells, and with different growth rates display greater variability. In reality, mother cells do exhibit a short G1; however, this G1 period is much less variable than the G1 phase exhibited by daughter cells at different growth rates (Hartwell \& Unger, 1977). Thus, the 'mixed mother-daughter' model of cell division seems appropriate to analyse the yeast cell cycle. 
When the absolute times spent in each stage of the cell cycle were calculated (Table 1), based on the equations derived by Slater et al. (1977), the length of G1 appeared to be most affected by altered growth rates. The times spent in G1 showed an approximately 10-fold difference at different generation times. The times spent in S and G2 also changed with growth rate, but this variation was markedly less than that exhibited by the times spent in G1. (Some variation in $\mathrm{S}$ may be due to the method of calculation since the proportion of cells in S is that not accounted for by G1 and G2; therefore, small proportional errors in estimating these cell cycle fractions may produce large errors in the estimates of S.) By employing different nitrogen sources, we observed an approximately 4-fold variation in time spent in S and a 1.6-fold variation in time spent in G2. Regardless of generation time, the time spent in S plus G2 appeared to be relatively constant (Table 1). Previously, we demonstrated that governing generation times by using different carbon sources caused no change in the time spent in S (Slater et al., 1977). The maximum generation time of these carbonlimited cultures was $4.3 \mathrm{~h}$. As shown in Fig. 3, nitrogen-limited cultures growing with generation times up to $4 \mathrm{~h}$ also showed a constant time for $\mathrm{S}$, and only at longer generation times was the time spent in $\mathrm{S}$ increased. Thus, results from carbon-limited cultures are consistent with these results from nitrogen-limited cultures.

In summary, the finding that the time in $\mathrm{S}$ increased at longer generation times is consistent with that of Rivin \& Fangman (1978). In contrast to the conclusions of these authors, however, here and elsewhere (Slater et al., 1977) we found that, regardless of growth rate, the initiation of budding was indistinguishable from the initiation of DNA synthesis. One apparent exception to this was for cells grown on threonine; however, we have not determined if this situation represents a general trend at even slower growth rates. As when growth rates were governed by carbon source, we again saw a constant period in the cell division cycle which appears to be that time required for S plus G2 (Carter et al., 1978; Slater et al., 1977). When generation times were altered using different nitrogen sources, the period of the cell division cycle most affected by such alterations was G1. This is consistent with our earlier suggestion that the rate-limiting step for initiation of cell division cycles is some event in G1 (Slater et al., 1977; Johnston et al., 1977b). Prior to initiation of the cell cycle and the initiation of a bud, growth to some critical size is required. These results reinforce the suggestion by Hartwell and his colleagues (Hartwell \& Unger, 1977; Johnston et al., 1977 b) that 'start' is the rate-limiting step for initiation of cell division.

The authors wish to thank C. J. Rivin and W. L. Fangman for making available their unpublished results.

\section{REFERENCES}

Carter, B. L. A., Lorincz, A. \& Johnston, G. C. (1978). Protein synthesis, cell division and the cell cycle in Saccharomyces cerevisiae following a shift to a richer medium. Journal of General Microbiology 106, 222-225.

Hartwell, L. H. (1970). Periodic density fluctuation during the yeast cell cycle and the selection of synchronous cultures. Journal of Bacteriology 104, 1280-1285.

HARTWELL, L. H. \& UNGER, M. W. (1977). Unequal division in Saccharomyces cerevisiae and its implications for the control of cell division. Journal of Cell Biology 75, 422-435.

Hereford, L. M. \& Hartwell, L. H. (1973). Role of protein synthesis in the replication of yeast DNA. Nature New Biology 244, 129-131.

JAGADISH, M. N. \& CARTER, B. L. A. (1977). Genetic control of cell division in yeast cultured at different growth rates. Nature, London 269, 145 147.

Johnston, G. C., Singer, R. A. \& McFarlane, E. S. $(1977 a)$. Growth and cell division during nitrogen starvation of the yeast Saccharomyces cerevisiae. Journal of Bacteriology 132, 723-730.

Johnston, G. C., Pringle, J. R. \& Hartwell, L. H. (1977b). Coordination of growth with cell division in the yeast Saccharomyces cerevisiae. Experimental Cell Research 105, 79-98.

Johnston, G. C., Ehrhardt, C. W., Lorincz, A. \& CARTER, B. L. A. (1979). Regulation of cell size in the yeast Saccharomyces cerevisiae. Journal of Bacteriology 137, 1-5.

Rivin, C. J. \& Fangman, W. L. (1978). Variation of the DNA synthesis phase in Saccharomyces cerevisiae. 9th International Conference on Yeast Genetics and Molecular Biology, p. 72 (abstract). 
Slater, M. L., Sharrow, S. O. \& Gart, J. J. Tobey, R. A. \& Chrissman, H. A. (1975). Unique (1977). Cell cycle of $S$. cerevisiae in populations growing at different rates. Proceedings of the National Academy of Sciences of the United States technique for cell cycle analysis utilizing mithraNational Academy of Sciect
of America 74, 3850-3854. Cell Research 93, 235-239. 